\title{
Grensoverschrijdende omzettingen
}

\author{
Polbud in perspectief
}

\author{
H. Koster
}

1

Inleiding

Op 25 oktober 2017 heeft het Hof van Justitie van de Europese Unie (hierna: het Hof) in het Polbud-arrest een nadere invulling gegeven aan de mogelijkheid van een grensoverschrijdende omzetting op basis van de vrijheid van vestiging van art. 49 en 54 van het Verdrag betreffende de werking van de Europese Unie (VWEU). ${ }^{1}$ Het Polbud-arrest is een belangrijke aanvulling op de reeds bestaande arresten over grensoverschrijdende herstructureringen in de EU. ${ }^{2}$ Eerder, op 16 december 2008, had het Hof al in het Cartesio-arrest geoordeeld dat grensoverschrijdende omzettingen binnen de EU toegestaan zijn, ${ }^{3}$ wanneer het recht van een andere EU-lidstaat van toepassing wordt op de betreffende vennootschap. In dit artikel analyseer ik wat het Polbud-arrest betekent in het perspectief van het geldende recht met betrekking tot grensoverschrijdende omzettingen. Ik zal daartoe in de volgende paragraaf eerst ingaan op de incorporatieleer en de werkelijke-zetelleer alsmede de relevante arresten over de vrijheid van vestiging die voor het Polbud-arrest waren gewezen. Vervolgens bespreek en analyseer ik in paragraaf 3 het Polbud-arrest ${ }^{4}$ en hoe dit arrest in het raamwerk van al eerder gewezen arresten past. Ik sluit in paragraaf 4 af met een conclusie.

\section{$2 \quad$ Vrijheid van vestiging voor Polbud}

\section{$2.1 \quad$ Vrijheid van vestiging}

In art. 49 VWEU is de voor de grensoverschrijdende omzetting relevante vrijheid van vestiging geregeld. In dat artikel is vastgelegd dat beperkingen van de vrijheid

1 HvJ EU 25 oktober 2017, C-106/16, ECLI:EU:C:2017:804.

2 Het arrest Polbud betreft overigens de wetgeving van de lidstaat van oprichting. Dit was ook het geval in de arresten Daily Mail, Cartesio en National Grid. De andere arresten over de vrijheid van vestiging van vennootschappen, te weten Centros, Inspire Art, Überseering, SEVIC Systems en Vale, hadden betrekking op de wetgeving van de lidstaat van ontvangst.

3 In de literatuur is geduid dat dergelijke grensoverschrijdende omzettingen mede verband houden met de voorkeur van vennootschappen voor een faciliterend vennootschapsrecht. Zie E. Ferran, Corporate mobility and company law, The Modern Law Review (79) 2016, afl. 5.

4 Zie hierover ook M.A. Verbrugh, Grensoverschrijdende zetelverplaatsing op grond van de vrijheid van vestiging: het laatste stukje van de puzzel in het Polbud-arrest?, A\&O 2018, afl. 1; G.C. van Eck \& E.R. Roelofs, Het Polbud-arrest: eerst (aan)komen, dan gaan?, TvOB 2018, afl. 2, p. 48-53; J.N. Schutte-Veenstra, Bespreking van het Polbud-arrest, Ondernemingsrecht 2018/8; O. Oost, T. Keijzer \& P. Suurd, Polbud: een paradigmawisseling voor grensoverschrijdende omzettingen?, AA 2017, p. 979-986; W.J.M. van Veen, Grensoverschrijdende omzetting, fusie en splitsing: waar ligt de grens?, WPNR 2017/7171. 
van vestiging voor onderdanen van een lidstaat op het grondgebied van een andere lidstaat verboden zijn. De vrijheid van vestiging omvat in beginsel - dit betreft het primaire vestigingsrecht - de toegang tot werkzaamheden anders dan in loondienst en de uitoefening daarvan alsmede de oprichting en het beheer van ondernemingen, en met name van vennootschappen, overeenkomstig de bepalingen die door de wetgeving van het land van vestiging voor de eigen onderdanen zijn vastgesteld. Deze vrijheid heeft eveneens betrekking op - dit betreft het secundaire recht van vestiging - beperkingen betreffende de oprichting van agentschappen, filialen of dochterondernemingen door de onderdanen van een lidstaat die op het grondgebied van een lidstaat zijn gevestigd. In art. 54 VWEU is bepaald voor welke vennootschappen dit geldt. Het betreft vennootschappen die in overeenstemming met de wetgeving van een lidstaat zijn opgericht en die hun statutaire zetel, hun hoofdbestuur of hun hoofdvestiging binnen de EU hebben. Onder vennootschappen worden in dit kader verstaan maatschappen naar burgerlijk recht of handelsrecht, de coöperatieve verenigingen of vennootschappen daaronder begrepen, en de overige rechtspersonen naar publiek- of privaatrecht, met uitzondering van vennootschappen die geen winst beogen. ${ }^{5}$

\subsection{Incorporatieleer en werkelijke zetelleer}

Van belang is dus dat het moet gaan om vennootschappen die in overeenstemming met de wetgeving van een lidstaat zijn opgericht en die in elk geval hun statutaire zetel, hun hoofdbestuur of hun hoofdvestiging binnen de EU hebben. Er wordt in dit kader ook wel gesproken over de incorporatieleer (statutaire zetel) en de werkelijke-zetelleer (hoofdbestuur of hoofdvestiging). ${ }^{6}$ Dit ziet op de vraag welk vennootschapsrecht van toepassing is op een vennootschap. Bij de incorporatieleer - dat onder andere in Nederland wordt toegepast ${ }^{7}$ - is het recht van toepassing volgens welke de vennootschap rechtsgeldig is opgericht dan wel waar zij haar statutaire zetel heeft. Is de werkelijke-zetelleer van toepassing, dan geldt het recht van het land waar de werkelijke zetel zich bevindt. De exacte reikwijdte van de werkelijke zetel is overigens nog niet volledig uitgekristalliseerd. Naast hoofdbestuur of hoofdvestiging wordt soms ook wel belang toegekend aan bijvoorbeeld de economische activiteiten van de vennootschap. ${ }^{8}$ Een aantal lidstaten is de laatste jaren overigens overgegaan naar toepassing van de incorporatieleer of is van plan om dat te doen. ${ }^{9}$ Dit onder meer omdat de incorporatieleer flexibeler is,

5 Zie over de grensoverschrijdende omzetting van personenvennootschappen naar Duits recht P. Maume \& M. Kellner, Grenzüberschreitende Mobilität von Personengesellschaften, ZGR (46) 2017, afl. 3. Zie voor de grensoverschrijdende omzetting van verenigingen M. Wesiack, Europäisches Internationales Vereinsrecht, Tübingen: Mohr Siebeck 2011.

6 Zie hierover uitgebreid M. Myszke-Nowakowska, The role of choice of law rules in shaping free movement of companies, Antwerpen: Intersentia 2014.

7 Zie verder X.E. Kramer \& H.L.E. Verhagen, Mr. C. Assers Handleiding tot de beoefening van het Nederlands burgerlijk recht. 10. Internationaal privaatrecht. Deel III. Internationaal vermogensrecht, Deventer: Wolters Kluwer 2015, nr. 1-3.

8 Zie hierover C. Gerner-Beuerle e.a., Study on the law applicable to companies (Final Report), LSE Enterprise 2016, p. 293 en noot 118.

9 Het betreft Hongarije en voor kapitaalvennootschappen Duitsland. België is van plan om over te gaan naar toepassing van de incorporatieleer. 
omdat het dan mogelijk is voor vennootschappen om vanuit lidstaten die de incorporatieleer toepassen, de werkelijke zetel naar het buitenland te verplaatsen. Voorts kunnen buitenlandse ondernemers een vennootschap in een incorporatieleer-lidstaat oprichten en dan met behulp van een filiaal in eigen land ondernemen. ${ }^{10}$ Als voordeel van de werkelijke-zetelleer wordt wel genoemd dat deze werkt als een mechanisme tot bescherming van stakeholders, zoals crediteuren, werknemers en minderheidsaandeelhouders. ${ }^{11}$ De werkelijke-zetelleer kan worden geduid als een 'piercing the veil' ten behoeve van de economische werkelijkheid. Door de EU-jurisprudentie is deze functie om misbruik tegen te gaan evenwel beperkt. Overigens kan het naast elkaar van toepassing zijn van de incorporatieleer en de werkelijke-zetelleer bij het verplaatsen van alleen de werkelijke zetel tot problemen leiden. Zo kan bij verplaatsing van de werkelijke zetel van een vennootschap van een land dat de werkelijke-zetelleer toepast naar een land dat de incorporatieleer toepast, ertoe leiden dat beide rechtsstelsels niet gelden. Is sprake van een verplaatsing van de statutaire zetel van een vennootschap van een land dat de werkelijke-zetelleer toepast naar een land dat de incorporatieleer toepast, dan kan dat ertoe leiden dat beide rechtsstelsels van toepassing zijn op de vennootschap.

\subsection{Daily Mail}

Het Hof heeft in een aantal uitspraken meer helderheid gecreëerd over de invulling van de vrijheid van vestiging betreffende vennootschappen. Het eerste belangrijke arrest is Daily Mail. ${ }^{12}$ Daily Mail betrof een Engelse vennootschap die met een beroep op de vrijheid van vestiging haar centrale bestuurszetel naar Nederland wenste te verhuizen, evenwel zonder toestemming van het ministerie van Financiën in het Verenigd Koninkrijk. Alhoewel het Verenigd Koninkrijk de incorporatieleer hanteert, was die verplaatsing van de werkelijke zetel wel relevant, omdat deze fiscaal als aanknopingsfactor gold. De uitspraak van het Hof in Daily Mail luidde dat de vrijheid van vestiging vennootschappen niet het recht geeft hun werkelijke zetel naar een andere lidstaat te verplaatsen als de vennootschap dit wenst te doen met behoud van haar rechtspersoonlijkheid en haar hoedanigheid van vennootschap naar het recht van het Verenigd Koninkrijk. Dit omdat het (toen nog) EEG Verdrag - maar dat geldt ook nu nog naar huidig Europees recht - de verschillen tussen de nationale wettelijke regelingen met betrekking tot de vereiste aanknoping en de vraag of, en zo ja hoe, de statutaire zetel of het feitelijke hoofdkantoor van een naar nationaal recht opgerichte vennootschap naar een andere lidstaat kan worden verplaatst, beschouwt als vraagstukken

10 Gerner-Beuerle e.a. stellen: "Countries that have a clear-cut version of the "incorporation theory" attract more incorporations than countries which have retained elements of the "real seat theory"'. Zie C. Gerner-Beuerle, F.M. Mucciarelli, E-P. Schuster \& M. Siems, Why do businesses incorporate in other EU Member States? An empirical analysis of the role of conflict of laws rules, International Review of Law and Economics 2018/56.

11 M. van de Looverbosch, Real seat theory $\mathrm{v}$ incorporation theory. The Belgium case for reform, International Company and Commercial Law Review 2017, afl. 1.

12 HvJ EG 27 september 1988, zaak 81/87 (The Queen/H.M. Treasury and Commissioners of Inland Revenue, ex parte Daily Mail and General Trust plc.). 
waarvoor de regels inzake het recht van vestiging geen oplossing bieden, maar die in toekomstige wetgeving of overeenkomsten moeten worden geregeld. ${ }^{13}$ De conclusie is aldus dat de vrijheid van vestiging op zichzelf niet in zijn algemeenheid het recht geeft op verplaatsing van de werkelijke of statutaire zetel. Gelet op het oogmerk van de EU, het nastreven van een gezamenlijke interne markt, is dit best wel een verrassende - of wellicht zelfs een onwenselijke? - uitkomst.

\section{$2.4 \quad$ Überseering}

Een volgende relevante uitspraak betreft het Überseering-arrest. ${ }^{14}$ Dit betrof een Nederlandse bv. De werkelijke leiding bevond zich in Duitsland. Het geschil betrof de omstandigheid dat de Duitse rechter de rechtsbevoegdheid van de Nederlandse vennootschap Überseering niet in een Duitse civiele procedure erkende, omdat de werkelijke zetel in Duitsland was gelegen maar de vennootschap niet naar Duits recht was opgericht. Het Hof oordeelde dat dit in strijd is met het recht op vrije vestiging, omdat EU-lidstaten de aanknopingsfactor van het land van oprichting dienen te erkennen. Aldus overwoog het Hof zowel in Daily Mail als in Überseering dat een op grond van een nationale rechtsorde opgerichte vennootschap enkel bestaat krachtens de nationale wetgeving. De keuze voor een aanknopingspunt, te weten statutaire zetel of werkelijke zetel is aan de lidstaten. De EU reguleert dit niet. Het Hof verbindt hier het gevolg aan dat de nationale wetgeving aldus ook 'de oprichtings- en werkingsvoorwaarden ervan bepaalt'. ${ }^{15}$ Dat betekent ook dat als een vennootschap is opgericht naar het recht van een lidstaat die de werkelijke-zetelleer hanteert en de vennootschap haar werkelijke zetel verplaatst naar een andere lidstaat, de vennootschap in elk geval naar het nationale recht van de lidstaat van vertrek niet meer kan bestaan. Überseering betekent eveneens dat als een vennootschap reeds bestaat naar het recht van een lidstaat en met die lidstaat een door dat land toegepast aanknopingspunt heeft, een andere lidstaat daar niet op een later moment op kan 'inbreken' door die vennootschap haar aanknopingspunt(en) voor te schijven en bij het daar niet aan voldoen als sanctie de vennootschap niet te erkennen. ${ }^{16}$ Dit kan voorts ook niet als de vennootschap tevens gaat voldoen aan een toegepast aanknopingspunt van die tweede lidstaat. Oftewel, is er eenmaal een connectie qua aanknopingspunt met een lidstaat, dan kan een vennootschap vanuit dat land activiteiten uit-

13 Daarover was in art. 220 EEG Verdrag (later art. 293 EG-verdrag) bepaald dat de lidstaten, voor zover nodig, overeenkomsten sluiten ter verzekering van, onder meer, de handhaving van de rechtspersoonlijkheid in geval van verplaatsing van de zetel van vennootschappen van het ene land naar het andere. Met betrekking tot deze materie is evenwel nimmer een overeenkomst van kracht geworden. De bepaling is niet meer teruggekeerd in het Verdrag van Lissabon. Aangenomen wordt evenwel dat dit nog steeds geldt. Zie J. Borg-Barthet, The governing law of companies in EU law, Oxford: Hart Publishing 2012, p. 110-111.

15 Daily Mail, r.o. 19; Überseering, r.o. 67.

16 Zie ook K. Geens \& M. Wyckaert, De kwestie van de zetel van de vennootschap: een perpetuum mobile?, in: Het vennootschapsbelang. Liber amicorum Herman Braeckmans, Antwerpen: Intersentia 2017, p. 220-221. 
oefenen in andere lidstaten. ${ }^{17}$ Überseering houdt aldus in dat een vennootschap gevestigd in een lidstaat door alle andere lidstaten in geval van zetelverplaatsing zonder verandering van recht (immigratie) moet worden erkend. Een andere lidstaat kan geen eisen stellen, bijvoorbeeld met betrekking tot aanknopingspunten. Het land van vestiging daarentegen kan wel aanknopingspunten voorschrijven conform Daily Mail en aldus zelfs in dergelijke gevallen emigratie tegenhouden. Samengevat, emigratie zonder verandering van recht is aan de individuele lidstaten om over te beslissen, bij immigratie moeten de lidstaten de nieuwkomer binnenlaten. Dit bevreemdt vanuit de gedachte dat logischerwijs lidstaten meer belang zouden moeten hebben bij wie er binnenkomt dan bij wie vertrekt. Vanuit EU-perspectief en het nastreven van een interne markt zou het overigens meer voor de hand liggen om zowel immigratie als emigratie vrij te laten. In dat kader zou er ook over kunnen worden nagedacht of vennootschappen niet de mogelijkheid kan worden gegeven om een keuze voor (het recht van) een bepaalde lidstaat te maken, zonder dat de statutaire of werkelijke zetel daarbij nog een rol speelt.

\subsection{Centros}

Een derde relevante uitspraak is het Centros-arrest. ${ }^{18}$ In Centros had een Deens echtpaar een Engelse limited opgericht, waarna met behulp van een filiaal alle activiteiten werden uitgeoefend in Denemarken. In Denemarken werd de inschrijving van het filiaal in het handelsregister evenwel geweigerd. Het Hof oordeelt dat de Deense weigering om het filiaal in het handelsregister in te schrijven in strijd is met het recht op vrije vestiging, omdat niet vereist is dat enige economische activiteit in het land van oprichting wordt verricht. Dit betekent dat in Denemarken geen vennootschap hoefde te worden opgericht en aan toepassing van de voorschriften inzake de oprichting van vennootschappen, die in Denemarken strenger waren met betrekking tot de storting van een minimumbedrag aan maatschappelijk kapitaal, werd ontkomen. Het Hof voegde daar wel aan toe dat dit niet uitsluit dat de autoriteiten van de betrokken lidstaat alle maatregelen kunnen treffen ter bestrijding of bestraffing van fraude. Dit kan hetzij ten aanzien van de vennootschap zelf, hetzij ten aanzien van aandeelhouders waarvan wordt aangetoond dat zij, via de oprichting van een vennootschap, in werkelijkheid trachten zich te onttrekken aan hun verplichtingen jegens particuliere of openbare schuldeisers die op het grondgebied van de betrokken lidstaat, waar de economische activiteiten worden verricht, gevestigd zijn. ${ }^{19}$

17 Zie ook M. Zilinsky, Grensoverschrijdende zetelverplaatsing en omzetting van vennootschappen in de Europese Unie: a never ending story?, in: G.F. Boulogne \& L.J.A. Pieterse (red.), Aanbevelingen ter verbetering van het vestigingsklimaat voor ondernemingen, Deventer: Kluwer 2012, p. 184 en 185.

18 HvJ EG 9 maart 1999, C-212/97.

19 Het feit dat een vennootschap geen activiteiten ontplooit in de lidstaat waar zij gevestigd is, en haar activiteiten uitsluitend uitoefent in de lidstaat van haar filiaal, volstaat evenwel niet voor het bewijs van misbruik of bedrog op grond waarvan laatstgenoemde lidstaat deze vennootschap een beroep op de communautaire bepalingen inzake het recht van vestiging zou kunnen ontzeggen. Zie Centros, r.o. 29. 


\subsection{Inspire Art}

Een vierde relevante uitspraak die ik noem, is het Inspire Art-arrest. ${ }^{20}$ Het zag op het naar Engels recht opgerichte Inspire Art Ltd. Deze limited had een Nederlands filiaal waar activiteiten werden uitgeoefend. Zij verrichtte in het Verenigd Koninkrijk geen enkele activiteit. In deze zaak oordeelde het Hof dat een lidstaat geen aanvullende eisen mag stellen aan het filiaal. Deze uitspraak van het Hof heeft ertoe geleid dat de Nederlandse Wet op de formeel buitenlandse vennootschappen is aangepast.

\subsection{Sevic Systems}

Een vijfde uitspraak die ik hier aanhaal, is het arrest van het Hof van 13 december 2005 inzake het Landsgericht Koblenz versus Sevic Systems AG. ${ }^{21}$ Sevic Systems AG, een Duitse rechtspersoon gevestigd te Neuwied, Duitsland, was in 2002 een juridische fusieovereenkomst aangegaan met Security Vision Concept SA, een Luxemburgse vennootschap gevestigd te Luxemburg. Door de juridische fusie zou Security Vision Concept SA als verdwijnende vennootschap ophouden te bestaan en haar vermogen zou overgaan op Sevic Systems AG, de verkrijgende vennootschap. Uit een rapport van de zitting blijkt dat sprake was van een moeder-dochterfusie, waarbij de dochter verdween, zodat een filiaal in Luxemburg ontstond. Verder betrof het een grensoverschrijdende fusie die naar het recht van Luxemburg rechtsgeldig plaatsvond. Toen Sevic Systems AG, teneinde de juridische fusie te voltooien, het handelsregister te Neuwied in Duitsland verzocht om de juridische fusie in te schrijven, werd dit geweigerd door het Amtsgericht waar dit handelsregister deel van uitmaakte, omdat niet alle betrokken vennootschappen hun zetel in Duitsland hadden, hetgeen de wettelijke regeling in Duitsland voorschreef. Service Systems AG ging hiertegen in beroep bij het Landsgericht Koblenz. Dit gerecht was van mening dat de beantwoording van het voorgelegde geschil afhankelijk was van de uitleg van art. 43 en 48 EG en legde daarom het Hof van Justitie van de Europese Gemeenschappen de prejudiciële vraag voor of er sprake was van strijd met art. 43 en 48 EG. Volgens het Hof was dat inderdaad het geval. Het Hof formuleerde het als volgt:

'In deze omstandigheden moet op de gestelde vraag worden geantwoord dat de artikelen 43 EG en 48 EG zich ertegen verzetten dat in een lidstaat de inschrijving in het nationaal handelsregister van een fusie door ontbinding zonder liquidatie van een vennootschap en door overdracht onder algemene titel van het vermogen ervan aan een andere vennootschap, in het algemeen

21 HvJ EG 13 december 2005, C-411/03. Zie hierover onder andere W.J.M. van Veen, Hof van Justitie EG over vestigingsvrijheid en grensoverschrijdende fusie; de fusierichtlijn vóór invoering achterhaald?, WPNR 2006/6657, de noten van J.N. Schutte-Veenstra in Ondernemingsrecht 2006, p. 115-119, B.J. Drijber in SEW 2006, p. 292-293 en G.-J. Vossestein in JOR 2006/33, M.J.G.C. Raaijmakers, Sevic: grensoverschrijdende fusie binnen de EU, AA 2006, p. 628-634, G.J.H. van der Sangen, Grenzenloze mobiliteit van ondernemingen na het Sevic-arrest, TvOB 2006, p. 178-186, en G.-J. Vossestein, Companies' freedom of establishment after Sevic, European Company Law 2006, p. 177-182. 
wordt geweigerd wanneer één van beide vennootschappen in een andere lidstaat is gevestigd, terwijl een dergelijke inschrijving mogelijk is, voorzover bepaalde voorwaarden zijn vervuld, wanneer beide bij de fusie betrokken vennootschappen op het grondgebied van de eerstbedoelde lidstaat zijn gevestigd.'

De reikwijdte van het Sevic-arrest is nader toegelicht in het hierna te bespreken Cartesio-arrest. In een overweging ten overvloede geeft het Hof aan:

'Wat vervolgens de invloed betreft van het reeds aangehaalde arrest SEVIC Systems op het in de arresten Daily Mail and General Trust en Überseering ontwikkelde beginsel, dient te worden vastgesteld dat deze arresten niet dezelfde problematiek betreffen, zodat niet kan worden betoogd dat eerstgenoemd arrest de strekking van de beide laatstgenoemde arresten nader heeft bepaald. De zaak waarin het arrest SEVIC Systems is gewezen betrof immers de erkenning, in de lidstaat van oprichting van een vennootschap, van een vestigingshandeling middels een grensoverschrijdende fusie door deze vennootschap in een andere lidstaat, welke situatie fundamenteel verschilt van de situatie die aan de orde was in de zaak die tot het arrest Daily Mail and General Trust heeft geleid. De situatie die aan orde was in de zaak waarin het arrest SEVIC Systems is gewezen, lijkt dus op situaties waarover andere arresten van het Hof zijn gewezen (zie arrest van 9 maart 1999, Centros, C-212/97, Jurispr. blz. I-1459; arrest Überseering, reeds aangehaald, en arrest van 30 september 2003, Inspire Art, C-167/01, Jurispr. blz. I-10155). In dergelijke situaties rijst echter niet de voorafgaande vraag, bedoeld in punt 109 van het onderhavige arrest, of de betrokken vennootschap kan worden aangemerkt als een vennootschap met de nationaliteit van de lidstaat volgens wiens wetgeving zij is opgericht, maar veeleer de vraag of deze vennootschap, waarvan vaststaat dat zij een vennootschap naar het nationale recht van een lidstaat is, al dan niet wordt geconfronteerd met een beperking in de uitoefening van haar recht om zich in een andere lidstaat te vestigen.'

Het Cartesio-arrest verduidelijkt dat het Sevic-arrest inhoudt dat een grensoverschrijdende fusie die naar het recht van het land waar de verdwijnende vennootschap was gevestigd rechtsgeldig is, in het land waar de verkrijgende vennootschap is gevestigd, erkend dient te worden. Een voorwaarde hierbij is dat het recht van de lidstaat van de verkrijgende vennootschap nationale juridische fusies toestaat. Mijns inziens geldt de regel van het Sevic-arrest ook voor grensoverschrijdende juridische splitsingen. Voorts volgt uit Sevic dat grensoverschrijdenden fusies, evenals overige omzettingen van vennootschappen zoals grensoverschrijdenden splitsingen, bijzondere wijzen van de uitoefening van de vrijheid van vestiging zijn. ${ }^{22}$ 


\subsection{Zetelverplaatsing en omzetting}

De laatste twee arresten die ik behandel, betreffen het al genoemde Cartesio en Vale. ${ }^{23}$ Beide zaken betroffen de vraag of sprake was van een grensoverschrijdende omzetting. Bij een omzetting kan sprake zijn van een binnenlandse of grensoverschrijdende omzetting en dit betreft één rechtshandeling. Naar Nederlands recht kunnen overigens alleen rechtspersonen zich omzetten. Kenmerkend voor een omzetting is dat de rechtsvorm wijzigt, terwijl de rechtspersoon blijft voortbestaan. Bij een grensoverschrijdende omzetting gaat het om een rechtsvorm van een lidstaat, die wijzigt in een rechtsvorm van een andere lidstaat, onder gelijktijdig voortbestaan van de rechtspersoon. Na de grensoverschrijdende omzetting is het vennootschapsrecht van het land van ontvangst van toepassing. Naast het voortbestaan van de rechtspersoon is een consequentie van de omzetting dat een wijziging van de statuten is vereist. Is sprake van een grensoverschrijdende omzetting, dan is tevens sprake van een verplaatsing van de statutaire zetel en/of de werkelijke zetel naar het land van ontvangst. Dit betekent dus ook dat een zetelverplaatsing niet hetzelfde is als een grensoverschrijdende omzetting, aangezien een grensoverschrijdende omzetting een zetelverplaatsing betreft - van de werkelijke en/of statutaire zetel - die tevens additioneel tot gevolg heeft dat het recht van een ander land van toepassing wordt op de rechtsvorm. Dit omdat niet elke zetelverplaatsing immers tot verandering van recht leidt. Het is het element 'verandering van recht' dat maakt dat sprake is van een grensoverschrijdende omzetting.

\subsection{Cartesio}

Cartesio betrof de verplaatsing van de werkelijke zetel ${ }^{24}$ van een Hongaarse commanditaire vennootschap naar Italië zonder verandering van het recht waaronder zij valt, aangezien de statutaire zetel van Cartesio in Hongarije bleef en Cartesio daardoor een vennootschap naar Hongaars recht bleef. ${ }^{25}$ Destijds gold in Hongarije volgens de wet dat de zetel van een vennootschap naar Hongaars recht de plaats is waar zich haar operationele bestuurscentrum bevindt. Aanvullend gold

23 HvJ EG 16 december 2008, C-210/06 (Cartesio) en HvJ EU 12 juli 2012, C-378/10 (Vale). Zie hierover M.A. Verbrugh, Grensoverschrijdende omzetting na de arresten Cartesio en Vale, SEW 2014, afl. 11.

24 Zie over de zetelverplaatsing ook C. Timmermans, Harmonization in the future of company law in Europe, in: K.J. Hopt \& E. Wymeersch (red.), Capital markets and company law, Oxford: Oxford University Press 2003.

25 De vennootschap Cartesio heeft als commanditair vennoot - die enkel verplicht is om kapitaal in te brengen - en als beherend vennoot - die onbeperkt aansprakelijk is voor alle schulden van de vennootschap - twee natuurlijke personen die in Hongarije wonen en de nationaliteit van deze lidstaat bezitten. Naar verluidt betrof het twee medewerkers van een universiteit in Hongarije die wilden testen of een dergelijke grensoverschrijdende omzetting is toegestaan op basis van de vrijheid van vestiging. Cartesio (Italiaans) zou verwijzen naar Cartesius. Dit is de Latijnse naam van (René) Descartes. Descartes was een beroemde Franse filosoof en wiskundige. Hij is de bedenker van de bekende spreuk 'ik denk, dus ik besta'. Door die spreuk zou voor de naam Cartesio zijn gekozen. Dit omdat in de kern het Cartesio-arrest erover ging of de vennootschap na verplaatsing van de werkelijke zetel nog kon bestaan. 
dat de statutaire zetel zich ook in Hongarije moest bevinden. ${ }^{26}$ Hongarije wilde de verplaatsing van de werkelijke zetel niet toestaan. Het Hof overwoog in Cartesio - opnieuw - dat

'een lidstaat zowel de aanknoping mag omschrijven die van een vennootschap vereist is opdat deze kan worden geacht te zijn opgericht volgens het nationale recht van die lidstaat, en uit dien hoofde het recht van vestiging heeft, als de aanknoping die vereist is om deze hoedanigheid naderhand te kunnen handhaven. Aldus omvat deze bevoegdheid de mogelijkheid voor deze lidstaat om een onder zijn nationale recht vallende vennootschap niet toe te staan deze hoedanigheid te behouden wanneer zij zich in een andere lidstaat wenst te herorganiseren door de verplaatsing van haar zetel naar het grondgebied van die lidstaat, en aldus de aanknoping die in het nationale recht van de lidstaat van oprichting is voorzien, verbreekt.' 27

\section{Ten overvloede overweegt het Hof vervolgens dat een}

'dergelijk geval van verplaatsing van de zetel zonder verandering van het recht waaronder zij valt, moet worden onderscheiden van het geval van de verplaatsing van een onder het recht van een lidstaat vallende vennootschap naar een andere lidstaat mét verandering van het toepasselijke nationale recht, waarbij de vennootschap wordt omgezet in een vennootschapsvorm die valt onder het nationale recht van de lidstaat waar zij naartoe is verplaatst'. ${ }^{28}$

Zou dit niet worden toegestaan, dan zou wel sprake zijn van een beperking van de vrijheid van vestiging, die verboden is. Dit tenzij zij wordt gerechtvaardigd door een dwingende reden van algemeen belang. Aldus was duidelijk dat grensoverschrijdende omzettingen binnen de EU toegestaan kunnen zijn, wanneer het recht van een andere EU-lidstaat van toepassing wordt op de desbetreffende vennootschap. ${ }^{29}$ Helaas ontbreekt tot op heden een wettelijke regeling, zodat er geen duidelijkheid bestaat over de te volgen procedure en de bescherming van de belangen van schuldeisers en minderheidsaandeelhouders. Het bewerkstelligen van een grensoverschrijdende omzetting is daardoor in de praktijk nog steeds met veel onzekerheden omgeven. Met Cartesio is duidelijk hoe het zit vanuit het land van vertrek, dat wil zeggen op basis van Cartesio is een outbound grensoverschrij-

26 Storm meent dat lidstaten, gelet op (destijds) art. 48 EG, niet beide aanknopingspunten tegelijkertijd kunnen voorschrijven. Zie P.M. Storm, Cartesio: stapjes in de processie van Echternach, Ondernemingsrecht 2009, afl. 7, p. 331. Mijns inziens ten onrechte. Een aanknopingspunt, maar ook een combinatie van aanknopingspunten betekent nog steeds dat sprake is van een onderdaan van de EU. Het EU-recht beperkt een combinatie niet, er is slechts geregeld dat minimaal één aanknopingspunt al voldoende is.

27 Zie r.o. 110.

28 Zie r.o. 111.

29 Zie ook A.F.M. Dorresteijn \& B. Verkerk, Nakaarten over Cartesio. Grensoverschrijdende zetelverplaatsing en omzetting, O\&F 2009, afl. 2, p. 55-68. Zie voorts ook Storm 2009 en J.B.S. Hijink, Grensoverschrijdende verplaatsingen van vennootschappen na Cartesio: enige juridische, fiscale en beleidsmatige overpeinzingen, Ondernemingsrecht 2010/77. 
dende omzetting toegestaan. Voor het land van ontvangst was dat anders, waarbij het Cartesio-arrest de vraag opriep wat het Hof met de woorden 'voor zover diens recht dit toestaat' bedoelde. In het arrest van het Hof van 12 juli 2012 inzake Vale is deze vraag beantwoord.

\subsection{Vale}

Vale betrof eveneens een geschil over een grensoverschrijdende omzetting, nu van een vennootschap naar Italiaans recht in een vennootschap naar Hongaars recht. ${ }^{30}$ Op 3 februari 2006 heeft Vale verzocht om doorhaling in het handelsregister te Rome, waarbij zij aangaf haar zetel en haar activiteiten naar Hongarije te willen verplaatsen en haar activiteiten in Italië te willen staken. Overeenkomstig dit verzoek is de inschrijving van deze vennootschap op 13 februari 2006 in het handelsregister doorgehaald. Blijkens het dossier is onder het opschrift 'doorhaling en zetelverplaatsing' in het handelsregister vermeld dat de vennootschap 'naar Hongarije is overgebracht'. De statuten zijn vervolgens aangepast en de naam van de vennootschap werd Vale Építési kft. Verder werd het kapitaal volgestort voor zover als volgens de Hongaarse wet voor inschrijving nodig was. Op 19 januari 2007 heeft een vertegenwoordiger van Vale bij de rechtbank te Boedapest een verzoek ingediend om inschrijving van de vennootschap volgens Hongaars recht. Dit verzoek werd door de rechtbank afgewezen. In hoger beroep bevestigde het regionale hof te Boedapest deze afwijzing, aangezien de nationale bepalingen over omzetting slechts op nationale omzettingen van toepassing zijn. Vale stelde vervolgens cassatieberoep in bij het hooggerechtshof en vorderde dat de afwijzingsbeschikking zou worden vernietigd en dat zij alsnog in het handelsregister wordt ingeschreven. Vale doet hierbij een beroep op art. 49 en 54 VWEU. Het hooggerechtshof besluit de behandeling van de zaak te schorsen en het Hof prejudiciële vragen te stellen. Het Hof wijst er allereerst op dat het Hof al in het arrest van 13 december 2005, SEVIC Systems (C-411/03) heeft geoordeeld dat omzettingen van vennootschappen in beginsel behoren tot de economische activiteiten waarvoor de lidstaten de vrijheid van vestiging moeten eerbiedigen. ${ }^{31}$ Daarbij geldt, zo het Hof:

'Wat het bestaan van een beperking van de vrijheid van vestiging betreft, zij eraan herinnerd dat het begrip vestiging in de zin van de verdragsbepalingen inzake de vrijheid van vestiging, de daadwerkelijke uitoefening van een economische activiteit voor onbepaalde tijd door middel van een duurzame vestiging in de lidstaat van ontvangst impliceert. Dit veronderstelt bijgevolg dat de betrokken vennootschap werkelijk gevestigd is in deze lidstaat en daar daadwerkelijk een economische activiteit uitoefent (arrest van 12 september

30 Zie over Vale ook E.R. Roelofs, Het Vale-arrest: een nieuwe stap op het gebied van grensoverschrijdende omzetting, WPNR 2012/6950 en W.J.M. van Veen, Grensoverschrijdende omzetting, -fusie en -splitsing na het Vale-arrest, WPNR 2013/6981.

31 Zie daarover S.M. van den Braak, Grensoverschrijdende omzetting van rechtspersonen, WPNR 2007/6721. 
2006, Cadbury Schweppes en Cadbury Schweppes Overseas, C-196/04, Jurispr. blz. I-7995, punt 54 en aldaar aangehaalde rechtspraak).'

Dit lijkt te betekenen dat volgens het Hof een vennootschap na een grensoverschrijdende omzetting een economische activiteit in het land van ontvangst moet verrichten. Dit is overigens iets anders dan de vraag of de werkelijke zetel in het land van ontvangst moet zijn gelegen na de omzetting. Voorts overweegt het Hof, en daarmee onduidelijkheid die door Cartesio was ontstaan wegnemend, dat:

'[d]e uitdrukking "voor zover diens recht dit toestaat" aan het einde van punt 112 van het reeds aangehaalde arrest Cartesio, niet aldus mag worden uitgelegd dat zij erop is gericht de wettelijke regeling van de lidstaat van ontvangst inzake de omzetting van vennootschappen onmiddellijk buiten de werkingssfeer van de regels van het VWEU inzake de vrijheid van vestiging te doen vallen, maar aldus moet worden uitgelegd dat zij de eenvoudige overweging weerspiegelt dat een op grond van een nationale rechtsorde opgerichte vennootschap enkel bestaat krachtens de nationale wetgeving, die aldus de oprichting van de vennootschap "toestaat", indien is voldaan aan de uit dien hoofde gestelde voorwaarden.'

Aldus concludeert het Hof dat een nationale regeling die, terwijl zij bepaalt dat nationale vennootschappen mogen worden omgezet, niet toestaat dat een vennootschap die onder het recht van een andere lidstaat valt, wordt omgezet, binnen de werkingssfeer van art. 49 en 54 VWEU valt. Vervolgens beoordeelt het Hof of er in dit geval sprake is van een beperking van de vrijheid van vestiging. Het Hof meent dat de aan de orde zijnde nationale regeling, aangezien deze enkel de omzetting van een vennootschap die reeds in de betrokken lidstaat is gevestigd toestaat, een verschil in behandeling van vennootschappen schept naargelang het een binnenlandse of een grensoverschrijdende omzetting betreft. Daardoor is sprake van een beperking in de zin van art. 49 en 54 VWEU. Aansluitend op Daily Mail betekent dit dat de vrijheid van vestiging op zichzelf niet het recht geeft op verplaatsing van de zetel, maar dat aan de vrijheid van vestiging wel rechten kunnen worden ontleend als sprake is van een toegestane verandering van nationaal recht. $^{32}$

Zijn er dan redenen die rechtvaardigen dat de vrijheid van vestiging wordt beperkt? Hierbij kan worden gedacht aan dwingende redenen van algemeen belang - zoals de bescherming van de belangen van de schuldeisers, de minderheidsaandeelhouders en de werknemers, de waarborging van de doeltreffendheid van de fiscale controles en de eerlijkheid van handelstransacties. Het moet daarbij gaan om een maatregel die geschikt is om de nagestreefde doelen te verwezenlijken en niet verder gaat dan wat nodig is om deze te bereiken. Het Hof oordeelt

32 Zie ook K. Maresceau, Grensoverschrijdenden mobiliteit van vennootschappen, Antwerpen: Intersentia 2014, p. 224-226. 
dat in dit geval een dergelijke rechtvaardiging ontbreekt. Dit omdat het Hongaarse recht in het algemeen grensoverschrijdende omzettingen niet toestaat.

Het Hof zet daarna uiteen dat, nu er thans geen specifieke EU-regels voor grensoverschrijdende omzettingen bestaan, het nationale recht van de staat van oorsprong, waaronder de vennootschap waarvan de omzetting wordt gevraagd valt, alsmede het nationale recht van de lidstaat van ontvangst, waaronder de uit deze omzetting ontstane vennootschap zal vallen, van toepassing is. ${ }^{33}$ Ook belangrijk is dat volgens het Hof een grensoverschrijdende omzetting in de lidstaat van ontvangst leidt tot de oprichting van een vennootschap naar het recht van die lidstaat. Oftewel, vanuit EU-perspectief kan een omzetting als 'oprichting' kwalificeren. Dit betekent dat het land van ontvangst dus zijn oprichtingsvoorschriften mag opleggen. Nieuw is dat het Hof in Vale ook oordeelt dat bij deze grensoverschrijdende omzettingen het gelijkwaardigheidsbeginsel en het doeltreffendheidsbeginsel gelden. Aldus was de weigering om de vennootschap van de lidstaat van oorsprong in het handelsregister als 'rechtsvoorgangster' van de omgezette vennootschap te vermelden, onverenigbaar met het gelijkwaardigheidsbeginsel aangezien deze vermelding van de rechtsvoorgangster wel wordt opgenomen bij binnenlandse omzettingen. Strijdig met het doeltreffendheidsbeginsel was dat geen rekening werd gehouden met van de autoriteiten van de lidstaat van oorsprong afkomstige documenten waaruit blijkt dat deze vennootschap niet langer onder het recht van de lidstaat van oorsprong valt. Het Hof zegt daarover dat:

'de lidstaat van ontvangst krachtens het doeltreffendheidsbeginsel bij het onderzoek van een verzoek om inschrijving van een vennootschap naar behoren [cursivering $\mathrm{HK}$ ] rekening moet houden met de van de autoriteiten van de lidstaat van oorsprong afkomstige documenten waaruit blijkt dat deze ven-

33 Het is onduidelijk of dit betekent dat naast het land van ontvangst ook het land van vertrek een nationale omzettingsregeling dient te kennen. Uit Vale, r.o. 43, luidend: 'In dit verband moet er in de eerste plaats aan worden herinnerd dat, aangezien het afgeleide Unierecht bij de huidige stand ervan niet voorziet in specifieke regels inzake grensoverschrijdende omzettingen, de bepalingen op grond waarvan een dergelijke verrichting mogelijk is zich slechts in het nationale recht kunnen bevinden, namelijk in het nationale recht van de staat van oorsprong, waaronder de vennootschap waarvan de omzetting wordt gevraagd valt, en in het nationale recht van de lidstaat van ontvangst, waaronder de uit deze omzetting ontstane vennootschap zal vallen', alsmede r.o. 44: 'Blijkens punt 37 van het onderhavige arrest is voor een grensoverschrijdende omzetting immers de opeenvolgende toepassing van twee nationale rechtsstelsels op deze rechtshandeling vereist', zou dit kunnen worden afgeleid. Maar uit r.o. 46, luidend: 'Zoals uit het antwoord op de eerste twee vragen volgt, verplichten de artikelen 49 VWEU en 54 VWEU immers een lidstaat die bepaalt dat vennootschappen naar binnenlands recht mogen worden omgezet, om deze mogelijkheid ook te bieden aan vennootschappen die onder het recht van een andere lidstaat vallen en waarvan de omzetting in vennootschappen naar nationaal recht van de eerste lidstaat wordt gevraagd', zou kunnen worden afgeleid dat dit alleen voor het land van ontvangst geldt. Voorts lijken ook r.o. 110-113 van Cartesio in deze richting te wijzen. Daar lijkt het vooral van belang te worden gevonden dat als een vennootschap met verandering van recht zich grensoverschrijdend wenst om te zetten, een land van vertrek dit niet mag belemmeren. Als een land geen nationale omzettingsregeling heeft, zou een beroep op het ontbreken van een dergelijke regeling als reden waarom dit niet kan worden toegestaan in het land van vertrek toch een belemmering vormen. 
nootschap zich werkelijk heeft aangepast aan de voorwaarden van deze lidstaat van oorsprong, voor zover zij verenigbaar zijn met het Unierecht'.

Het is de vraag wat de betekenis is van 'naar behoren rekening houden met'. Deze bewoordingen lijken enige vrijheid voor de lidstaten in te houden om bijvoorbeeld documenten te weigeren bij gerechtvaardigde twijfel over de juistheid ervan. Aldus is met Vale nu ook duidelijk hoe het zit in het land van ontvangst, dat wil zeggen op basis van Vale is een inbound grensoverschrijdende omzetting toegestaan.

\subsection{Afsluitend}

Enige conclusies ter afronding:

- Een herkomststaat mag naar huidig recht eisen dat een vennootschap, om aan zijn recht onderworpen te zijn en te blijven, ${ }^{34}$ voldoet aan de aanknopingspunten van dat herkomstland - zijnde de werkelijke zetel of de statutaire zetel of zelfs beide -, dit omdat het door een lidstaat gekozen aanknopingspunt ter vrije keuze staat van die lidstaat en niet door EU-regels wordt beperkt.

- Een vennootschap die geldig is opgericht en bestaat in de herkomststaat die de incorporatieleer hanteert, en haar werkelijke zetel verplaatst naar een andere lidstaat die de werkelijke-zetelleer toepast, terwijl de vennootschap na deze zetelverplaatsing dus niettemin blijft bestaan in de herkomststaat, moet door het land van ontvangst worden erkend als rechtspersoon naar het recht van de herkomststaat. Het land van ontvangst mag de rechtspersoonlijkheid van de vennootschap niet ontkennen en ook de vennootschap niet dwingen om zich om te zetten in een vennootschap naar het recht van het land van ontvangst noch deze vennootschap bijkomende verplichtingen opleggen.

- De bevoegdheid van een lidstaat tot keuze van een aanknopingspunt omvat ook de mogelijkheid voor deze lidstaat om een onder zijn nationale recht vallende vennootschap niet toe te staan deze hoedanigheid te behouden wanneer zij zich in een andere lidstaat wenst te herorganiseren door de verplaatsing van haar zetel naar het grondgebied van die lidstaat, en aldus de aanknoping die in het nationale recht van de lidstaat van herkomst is voorzien, verbreekt. Alsdan is in beginsel niet langer sprake van een vennootschap die onder de definitie van vennootschap in art. 54 VWEU valt, waardoor het recht op vrije vestiging niet langer kan worden ingeroepen.

- Wenst een vennootschap het toepasselijke recht evenwel te veranderen, dan mag het land van vertrek deze grensoverschrijdende omzetting niet tegenhouden door ontbinding en liquidatie te eisen, voor zover het gastland deze omzetting toestaat.

- Een land van ontvangst is verplicht een vennootschap uit een andere lidstaat te aanvaarden als vennootschap onderworpen aan zijn recht, met inachtneming van dezelfde voorwaarden als het land van ontvangst zou stellen aan 
een vennootschap die vanaf de eerste oprichting aan zijn recht is onderworpen.

- Als het Hof het heeft over 'verplaatsing van de zetel', betreft dat een verplaatsing zonder verandering van het recht, en als het Hof het heeft over 'verplaatsing van een vennootschap' naar een andere lidstaat, betreft dat een verplaatsing met verandering van het toepasselijke nationale recht. ${ }^{35}$

- Op een grensoverschrijdende omzetting - een verplaatsing van een vennootschap met verandering van recht - is bij gebreke van EU-regelgeving het nationale recht van de staat van oorsprong van toepassing alsmede het nationale recht van de lidstaat van ontvangst.

- Een grensoverschrijdende omzetting leidt in de lidstaat van ontvangst tot de 'oprichting' van een vennootschap naar het recht van die lidstaat, hetgeen betekent dat het land van ontvangst zijn oprichtingsvoorschriften mag opleggen.

- Een grensoverschrijdende fusie is, evenals overige omzettingen van vennootschappen, waaronder ook grensoverschrijdenden splitsingen, een bijzondere wijze van de uitoefening van de vrijheid van vestiging.

- Een grensoverschrijdende fusie (maar dit geldt ook voor een grensoverschrijdende splitsing) die naar het recht van het land waar de verdwijnende vennootschap was gevestigd, rechtsgeldig is, dient in het land waar de verkrijgende vennootschap is gevestigd, erkend te worden, mits het recht van de lidstaat van de verkrijgende vennootschap nationale juridische fusies toestaat.

- Het begrip vestiging in de zin van de verdragsbepalingen inzake de vrijheid van vestiging impliceert de daadwerkelijke uitoefening van een economische activiteit voor onbepaalde tijd door middel van een duurzame vestiging in de lidstaat van ontvangst.

- Onduidelijk is of een verplaatsing van alleen de statutaire zetel is toegestaan.

- De vrijheid van vestiging op zichzelf geeft niet in zijn algemeenheid het recht op verplaatsing van de werkelijke of statutaire zetel. Gelet op het oogmerk van de EU, het nastreven van een gezamenlijke interne markt, is dit best wel een verrassende - of zelfs wellicht een onwenselijke? - uitkomst.

- Gelet op onder andere Daily Mail en Überseering geldt dat emigratie zonder verandering van recht aan de individuele lidstaten is om over te beslissen, terwijl bij immigratie de lidstaten de nieuwkomer moeten binnenlaten. Vanuit EU-perspectief en het nastreven van een interne markt zou het meer voor de hand liggen om zowel immigratie als emigratie vrij te laten. In dat kader zou er ook over kunnen worden nagedacht of vennootschappen niet de mogelijkheid kan worden gegeven om een keuze voor (het recht van) een bepaalde lidstaat te maken, zonder dat de statutaire of werkelijke zetel daarbij nog een rol speelt.

- Zetelverplaatsingen en grensoverschrijdende omzettingen betreffen ingewikkelde materie. 
Het arrest betrof Polbud - Wykonawstwo sp. z o.o., in liquidatie (hierna: Polbud), een door Pools recht beheerste vennootschap. Polbud had haar statutaire zetel en volgens Polbud ook haar werkelijke zetel, maar het Hof beoordeelde de kwestie alsof alleen de statutaire zetel was verplaatst, hetgeen dit arrest daardoor voor de praktijk van groot belang maakt, omdat exact over die vraag nog onduidelijkheid bestond - van Polen naar Luxemburg verplaatst en verzocht tot doorhaling van haar inschrijving in het Poolse handelsregister na de zetelverplaatsing naar Luxemburg. In dat kader verzocht het Poolse handelsregister om enkele documenten die bij liquidatie van een rechtspersoon aangeleverd dienen te worden. Dit zag onder andere op documenten over besluitvorming en over de aanwijzing van de bewaarder van boeken en bescheiden van de vennootschap alsmede over een financiële verantwoording. Polbud meende dat ze deze documenten niet hoefde te overleggen, omdat geen sprake was van ontbinding, maar van verplaatsing van de vennootschap - dus met verandering van recht - naar Luxemburg. Omdat Polbud de gevraagde documenten niet aanleverde, besloot de rechter wiens taak het was om het Poolse handelsregister bij te houden, het verzoek tot doorhaling van de inschrijving van Polbud uit het Poolse handelsregister af te wijzen. Zowel in eerste aanleg als in hoger beroep is het hiertegen door Polbud ingestelde beroep afgewezen. In cassatie betoogde Polbud dat zij op de datum van de verplaatsing naar Luxemburg haar hoedanigheid van vennootschap naar Pools recht had verloren en een vennootschap naar Luxemburgs recht was geworden. Dit betekende volgens Polbud dat de liquidatieprocedure ten onrechte was toegepast in het kader van de beëindiging van haar inschrijving in het Poolse handelsregister. Aanvullend voerde Polbud aan dat zij bovendien onmogelijk de vereisten van de liquidatieprocedure kon naleven, omdat Polbud als rechtspersoon was blijven bestaan.

In dit kader is relevant dat Polbud het Hof na afronding van de mondelinge behandeling en publicatie van de conclusie van de A-G verzocht had om de heropening van de mondelinge behandeling teneinde de feitelijke omstandigheden van het hoofdgeding te verduidelijken.

Dit omdat zij in wezen, zo voert Polbud aan, anders dan blijkt uit het verzoek om een prejudiciële beslissing dat lijkt uit te gaan van alleen verplaatsing van de statutaire zetel, van plan was om zowel haar statutaire zetel als haar werkelijke zetel naar Luxemburg te verplaatsen. Gelet op het feit dat Luxemburg de werkelijkezetelleer aanhangt, is dit verzoek begrijpelijk, omdat Polbud zonder verplaatsing van ook de werkelijke zetel zich niet grensoverschrijdend kan omzetten naar Luxemburg. Omdat Polen ook de werkelijke-zetelleer volgt, zou Polbud dan, zo lijkt het, een Poolse vennootschap blijven. Het Hof wijst dit verzoek evenwel af, waardoor het Hof als uitgangspunt hanteert dat Polbud niet de bedoeling had om naast haar statutaire zetel ook haar werkelijke zetel naar Luxemburg te verplaatsen. Daarmee beoordeelde het Hof de kwestie alsof alleen de statutaire zetel was verplaatst, een voor de praktijk belangrijk vraagstuk, omdat hier nog onduidelijkheid over bestond. Dat neemt niet weg dat nu zowel Polen als Luxemburg de wer- 
kelijke-zetelleer hanteert, deze invulling van het geschil maakt dat eigenlijk geen sprake kan zijn van een grensoverschrijdende omzetting, oftewel een verplaatsing van de vennootschap met verandering van recht. Dit was vermoedelijk waarom Polbud verduidelijkt wenste te zien dat het ook om een verplaatsing van de werkelijke zetel ging. Wat hier verder ook van zij, het Hof heeft dit aspect genegeerd en met dit arrest de kans aangegrepen om te verduidelijken wat geldt wanneer alleen de statutaire zetel wordt verplaatst.

Er zijn in deze kwestie drie prejudiciële vragen gesteld. Het Hof behandelt de derde vraag als eerste en overweegt dat de verwijzende rechter in wezen wenst te vernemen - en daarmee herformuleert het Hof de derde vraag - of art. 49 en 54 VWEU aldus moeten worden uitgelegd dat de vrijheid van vestiging van toepassing is op de verplaatsing van de statutaire zetel van een naar het recht van een lidstaat opgerichte vennootschap naar het grondgebied van een andere lidstaat met het oog op de omzetting in een vennootschap naar het recht van die andere lidstaat, zonder verplaatsing van de werkelijke zetel van die vennootschap.

Het Hof oordeelt ter zake van deze derde vraag dat art. 49 en 54 VWEU de vrijheid van vestiging toekennen aan vennootschappen die in overeenstemming met de wetgeving van een lidstaat zijn opgericht en die hun statutaire zetel, hun hoofdbestuur of hun hoofdvestiging binnen de Europese Unie hebben, en dat daarom Polbud, die is opgericht in overeenstemming met de wetgeving van Polen, een EU-lidstaat, zich in beginsel op die vrijheid kan beroepen. Dat betekent dat Polbud op basis van de vrijheid van vestiging van art. 49 VWEU het recht toekomt om zich om te zetten in een vennootschap naar Luxemburgs recht, voor zover is voldaan aan de in het Luxemburgse recht gestelde oprichtingsvoorwaarden, ${ }^{36}$ in het bijzonder aan het criterium - dat betreft voor Luxemburg de werkelijke-zetelleer ${ }^{37}$ - dat door Luxemburg is gekozen voor de aanknoping van een vennootschap met zijn nationale rechtsorde. ${ }^{38}$ Dit omdat immers de omschrijving van het element van aanknoping dat bepaalt onder welk nationaal recht een vennootschap valt, gelet op art. 54 VWEU, tot de bevoegdheid van elke lidstaat behoort. ${ }^{39}$

Door de Poolse regering en de Oostenrijkse regering is in dit kader aangevoerd dat art. 49 en 54 VWEU niet van toepassing zijn op de verplaatsing van een vennootschap als aan de orde in het hoofdgeding. Dit omdat volgens de Oostenrijkse regering de vrijheid van vestiging niet kan worden ingeroepen wanneer de verplaatsing van de zetel niet is gegrond op de uitoefening van een werkelijke economische activiteit door middel van een duurzame vestiging in de lidstaat van ont-

Het Hof verwijst daarbij naar het arrest Daily Mail, punt 17.

Op grond van art. 159 van de Luxemburgse wet van 10 augustus 1915 betreffende het vennootschapsrecht hanteert Luxemburg het stelsel van de werkelijke zetel.

Dat zou dus in dit geval betekenen dat zonder verplaatsing van de werkelijke zetel dit niet kan.

Omdat het Hof de kwestie - ten onrechte, zo lijkt het - zo heeft opgevat dat alleen de statutaire zetel overging, zou hier dus niet aan worden voldaan. 
vangst. ${ }^{40}$ De Poolse regering beroept zich met name op de arresten Daily Mail en Cartesio. Over het argument van de Oostenrijkse regering, dat Polbud in de lidstaat van ontvangst geen werkelijke economische activiteit uitoefent, overweegt het Hof dat dit argument niet kan worden aanvaard. ${ }^{41}$ Het Hof verwijst daarvoor naar Centros, in feite het spiegelbeeld van Polbud. ${ }^{42}$ In dat arrest heeft het Hof immers reeds geoordeeld dat een situatie waarin een naar het recht van een lidstaat opgerichte vennootschap, met statutaire zetel in deze lidstaat, een filiaal in een andere lidstaat wenst op te richten, onder de vrijheid van vestiging valt, ook al is die vennootschap in de eerste lidstaat enkel opgericht met het doel zich te vestigen in de tweede lidstaat, om daar haar voornaamste, zo niet al haar economische activiteiten te ontplooien. Aldus valt ook een situatie waarin een overeenkomstig de wetgeving van een lidstaat opgerichte vennootschap zich wenst om te zetten in een vennootschap naar het recht van een andere lidstaat, overeenkomstig het criterium van die andere lidstaat voor de aanknoping van een vennootschap aan zijn nationale rechtsorde, onder de vrijheid van vestiging, ook al ontplooit die vennootschap haar voornaamste, zo niet al haar economische activiteiten in de lidstaat van vertrek.

Voorts wijst het Hof erop dat de vestiging van de statutaire of werkelijke zetel van een vennootschap overeenkomstig de wetgeving van een lidstaat met het doel voor een gunstigere wetgeving in aanmerking te komen, op zich geen misbruik oplevert. ${ }^{43}$ Daarnaast overweegt het Hof dat uit Daily Mail en Cartesio, anders dan de Poolse regering heeft aangevoerd, niet blijkt dat, om onder de vrijheid van vestiging te vallen, de verplaatsing van de statutaire zetel van een vennootschap noodzakelijkerwijs - dat hangt namelijk af van het/de aanknopingspunt(en) die het land van ontvangst kent - gepaard moet gaan met de verplaatsing van haar werkelijke zetel. Aldus is het dan niet van belang of een vennootschap een economische activiteit uitoefent in de lidstaat van ontvangst. Het belang dat het Hof in het Vale-arrest nog leek te hechten voor het begrip vestiging aan de 'daadwerkelijke uitoefening van een economische activiteit voor onbepaalde tijd door middel van een duurzame vestiging in de lidstaat van ontvangst' lijkt daarmee te zijn verlaten. ${ }^{44}$

Het Hof beantwoordt vervolgens de eerste en tweede vraag. Het Hof verduidelijkt dat de verwijzende rechter in wezen wenst te vernemen of art. 49 en 54 VWEU

40 Zo ook de A-G in zijn conclusie voor Polbud. De A-G stelt dat een beroep op de vrijheid van vestiging de daadwerkelijke uitoefening van een economische activiteit voor onbepaalde tijd door middel van een duurzame vestiging in de lidstaat van ontvangst vereist, of althans de intentie daartoe.

41 Zie in deze zin ook al eerder C.W.A. Timmermans, Symposium Cartesio: een commentaar, in: J.B.S. Hijink, M.A. Verbrugh e.a. (red.), Europees ondernemingsrecht: grensoverschrijdend ondernemen na Cartesio, Deventer: Kluwer 2012, par. 4.2.

42 Centros, punt 17. Immers, het oprichten van een filiaal in een andere lidstaat, waarvan de werkzaamheden de voornaamste of zelfs enige economische activiteiten van de vennootschap zullen vormen, valt onder de vrijheid van vestiging

43 Zie in die zin ook Centros, punt 27, en Inspire Art, punt 96.

44 Zie r.o. 34. 
aldus moeten worden uitgelegd dat zij in de weg staan aan een regeling van een lidstaat die de verplaatsing van de statutaire zetel van een naar het recht van een lidstaat opgerichte vennootschap naar het grondgebied van een andere lidstaat met het oog op de omzetting in een vennootschap naar het recht van die andere lidstaat, overeenkomstig de voorwaarden die de wetgeving van deze laatste lidstaat oplegt, afhankelijk stelt van de liquidatie van de eerste vennootschap. In dat kader is volgens het Hof van belang dat op basis van art. 49 VWEU beperkingen van de vrijheid van vestiging moeten worden opgeheven en dat het vaste rechtspraak is dat als beperkingen van de vrijheid van vestiging moeten worden beschouwd alle maatregelen die de uitoefening van deze vrijheid verbieden, belemmeren of minder aantrekkelijk maken. ${ }^{45}$ Het Hof oordeelt dat de Poolse regeling, door de liquidatie van de vennootschap te vereisen en in verband hiermee bepaalde handelingen, de grensoverschrijdende verplaatsing van een vennootschap kan belemmeren of zelfs beletten. Dit vormt een beperking van de vrijheid van vestiging. Volgens vaste rechtspraak van het Hof is een dergelijke beperking van de vrijheid van vestiging slechts toelaatbaar wanneer zij gerechtvaardigd is uit hoofde van dwingende redenen van algemeen belang. Daarenboven moet die beperking geschikt zijn om de betrokken doelstelling te verwezenlijken en mag zij niet verder gaan dan nodig is om die doelstelling te verwezenlijken (de proportionaliteitstoets en de subsidiariteitstoets). ${ }^{46}$ Meer specifiek geldt dat art. 49 en 54 VWEU zich in beginsel niet verzetten tegen maatregelen van een lidstaat die ertoe strekken dat de belangen van de schuldeisers, de minderheidsaandeelhouders en de werknemers van een vennootschap die naar zijn recht is opgericht en die haar activiteiten op het nationale grondgebied blijft uitoefenen, niet onterecht worden geraakt door de verplaatsing van de statutaire zetel van die vennootschap en de omzetting ervan in een vennootschap naar het recht van een andere lidstaat. Van belang is dat de Poolse regeling die in een verplichting tot liquidatie voorziet, zonder dat rekening wordt gehouden met het werkelijke risico op schending van de belangen van de schuldeisers, de minderheidsaandeelhouders en de werknemers, en zonder dat kan worden gekozen voor minder beperkende maatregelen die deze belangen kunnen beschermen, daarmee verder gaat dan nodig is. Het Hof oordeelt aldus dat een algemene verplichting om een liquidatieprocedure te volgen als onevenredig moet worden beschouwd.

\section{$4 \quad$ Conclusie}

Met het Polbud-arrest is duidelijk geworden dat het (daadwerkelijk) uitoefenen van economische activiteiten in de lidstaat van ontvangst, zoals Vale leek te impliceren, in zijn algemeenheid geen vereiste is voor grensoverschrijdende omzettingen. Om onder de vrijheid van vestiging te vallen is derhalve in zijn algemeenheid ook niet vereist dat de verplaatsing van de statutaire zetel van een vennootschap noodzakelijkerwijs gepaard moet gaan met de verplaatsing van haar 
werkelijke zetel. Dit alles neemt evenwel niet weg dat een EU-regeling voor grensoverschrijdende omzettingen nog steeds wenselijk is, onder andere om procedurele regels te geven alsmede regels over bescherming van betrokkenen. Op dat vlak is positief nieuws te melden, nu de Europese Commissie op 25 april 2018 een voorstel heeft gepubliceerd voor een wijziging van Richtlijn (EU) 2017/1132 met betrekking tot onder andere grensoverschrijdende omzetting. Ik hoop dat de EU nu doorzet en met een regeling komt. De praktijk is daar zeker bij gebaat. 